\section{Commission's directive in balance}

Brussels

UNLESS they can hammer out several major political compromises, environment ministers of the European Communities meeting here next week (6 December) have little chance of getting to grips with the problem of air pollution.

For the past several weeks, discussions of the draft directive on limiting emissions from large combustion plants have shown little sign that the member governments are prepared to relax the positions they defended at the last council in June. If anything, they seem more firmly entrenched, at least to judge from the number of objections lodged to this important and controversial piece of Community legislation.

The Commission wants to see air pollution programmes in force by 1 January 1985. The draft directive would set uniform emission standards for sulphur dioxide, nitrogen oxides and dust from plants with a thermal output of 50 megawatts or more. Its aim is to reduce, by 1995 , the volume of sulphur dioxide emitted by 60 per cent (compared with 1980), and dust and nitrogen oxides by 40 per cent.

The member governments, however, remain divided both on the particular emission limits in the draft directive and on the principle whether there should be global emission standards at all.

In the forefront of opposition to the directive is the United Kingdom, which argues that deadlines are not necessary because scientific evidence on the contribution of industrial plants to air pollution is still incomplete, and that the cost to industry of implementing the directive would not be offset by its effects on the environment. According to the Commission, the extra cost of fitting new combustion plants with desulphurization equipment to remove 90 per cent of sulphur from fuel gases to achieve the limit of $400 \mathrm{mg}$ of sulphur dioxide per cubic metre would be US\$100 per kilowatt of electricity produced.

Other opponents of the directive are Greece and Ireland, both of them conscious that their industrial emissions are likely to increase in future. Greece is planning new generating plants using its own indigenous and particularly polluting fuel. Ireland, for this half-year the president of the council, is in a ticklish position, having to show itself in a forceful role while having to replace much natural gas usage by coal-fired electricity generating plants.

Luxembourg, which has no plants that would now be affected by the directive, is also worried about the future, while Italy, which also opposes the directive, is asking that emission limits should be fixed nationally, not at Community level.

The emission limits proposed by the Commission are, however, considered too weak by West Germany and the Netherlands. Denmark, which is in favour of the directive, also considers the emission limits too strict, especially for nitrogen oxides and dust.

Indeed, several governments would prefer to see dust left out of the directive altogether, partly because monitoring of dust emissions can be up to 50 per cent in error and because of the lack of data about present practice. The British want the directive to apply only to steam or electricity generators and not to the cement works, brick works and/or treatment plants that would at present be included. While some (including France, Ireland, the Netherlands and Italy) consider these a dangerous source of nitrogen oxides, other governments insist that control technology is at present inadequate for the directive to be effective.

There is also disagreement about the size of plants to which controls should apply. The United Kingdom has proposed a 100 MW threshold, Ireland $150 \mathrm{MW}$. Although the Commission's proposal includes a number of temporary exemptions, as when costs of compliance would be disproportionately high or when total annual emissions are lower than in other countries, even these are considered insufficient by countries such as Greece, Ireland and Luxembourg.

The Irish presidency's search for a compromise is turning out to be difficult. Three proposals have been put forward.

- Limiting the directive to new plant, which West Germany fears would allow too much plant now planned or being built to escape regulation by the time the Community directive is turned into national law.

- Raising the threshold to $150 \mathrm{MW}$, to which some object that the result would be more small plants and thus more pollution in total.

- A quota system with national emission rates fixed on criteria such as the level of energy consumption and the contribution to transboundary pollution. Belgium objects on the grounds that this compromise would be discriminatory and West Germany on the grounds that it violates the polluter-pays principle. The Commission itself fears that this compromise would conflict with Community law.

At next week's meeting, the ten governments will be equally divided, with Britain, Greece, Ireland, Italy and Luxembourg in opposition. A further complication is that the Commission's draft directive has been severely criticized by the European Parliament on the grounds that it is too lax. Ursula Schleicher, West German Member of the European Parliament, for example, says that the five-year exemption for plants below $100 \mathrm{MW}$ will generate the building of small plants. She also advocates a supraregional monitoring system for air pollution and financial support from the Community to deal with regional problems.

The European Parliament itself has called for the application of the standards to existing plants and for stricter emission values by the end of 1990 .

Another contentious issue next week is that of phasing lead out of petrol (see Nature 4 October, p.401). The council will be able to take a decision only in principle, because the European Parliament's opinion has been blocked by the 158 amendments submitted during its last session.

Denmark, Luxembourg and the Netherlands have, however, joined West Germany in their willingness to introduce lead-free petrol by 1986 while others would agree that this date should be optional (with the exception of Greece, which is unhappy about the whole thing). France is saying that the interim standard of 0.15 grams of lead per litre of petrol need not be included in the directive.

Among the other issues that will be discussed next week are a proposal that Community governments should aim at US emission levels from automobiles by 1986 rather than 1988, but again there are differing opinions about the need for an interim set of emission standards. The meeting will also have to decide whether to spend 100 million ECUs on a five-year programme to protect forests from fires as well as acid rain, chiefly by setting up a monitoring network. Anna Lubinska

\section{New climate unit}

A NEW centre for atmospheric and oceanographic reseach was opened at the University of Oxford two weeks ago by the chairman of the UK University Grants Committee, Sir Peter Swinnerton-Dyer, in his capacity as chairman of the Meteorological Committee, which answers to the Secretary of State for Defence. The new centre, which promises to play a significant role in both satellite meteorology and largescale oceanographic-climate modelling, is unique in being administered and supported by the Meteorological Office while being located in a university department - Oxford's department of atmospheric physics.

Most of the staff at the new unit are drawn from the Meteorological Office, with the addition of Dr Adrian Gill, a theoretical oceanographer (who until recently was at the University of Cambridge). The staff are drawn equally from the fields of numerical oceanography and satellite meteorology, and the expectation is that close proximity to the atmospheric and remote sensing expertise at Oxford will focus and stimulate research on such problems as tropical climate-ocean interactions and satellite sea-surface measurements. Philip Campbell 